Bull. Chem. Soc. Ethiop. 2012, 26(1), 65-72.

Printed in Ethiopia

ISSN 1011-3924

DOI: http://dx.doi.org/10.4314/bcse.v26i1.7

(c) 2012 Chemical Society of Ethiopia

\title{
PVC-MEMBRANE POTENTIOMETRIC SENSORS BASED ON A RECENTLY SYNTHESIZED SCHIFF BASE FOR Fe(III) ION
}

\author{
Iran Sheikhshoaie $^{1,2^{*}}$, Tayebeh Shamspur ${ }^{1,3}$, Ali Mostafavi ${ }^{1}$ and S. Yousef Ebrahimipur ${ }^{4}$ \\ ${ }^{1}$ Chemistry Department, Shahid Bahonar University, Kerman, Iran \\ ${ }^{2}$ Group of Organometallic Catalysts, Shahid Bahonar University, Kerman, Iran \\ ${ }^{3}$ Mineral Industry Research Institute, Shahid Bahonar University, Kerman, Iran \\ ${ }^{4}$ Chemistry Department, Payame-Noor University (PNU), Kerman, Iran
}

(Received October 8, 2010; revised May 10, 2011)

\begin{abstract}
A potentiometric iron sensor based on the use 3-(2-diethylamino-ethylimino)-1,3-dihydro-indol2-one (DEDIO) as an ionophore in poly(vinyl chloride) (PVC) matrix, is reported. The plasticized membrane sensor exhibits a Nernstian response for Fe(III) ions over a wide concentration range $\left(2.0 \times 10^{-6}-5.0 \times 10^{-2} \mathrm{M}\right)$ with a super Nernstian slope of $26( \pm 1) \mathrm{mV}$ per decade. It has a fast response time of $<12 \mathrm{~s}$ and can be used for ten weeks without any considerable divergences in its potentials the electrode can be used in the $\mathrm{pH}$ range 4.5-8.0. The proposed sensor shows fairly good discriminating ability towards Fe(III) ion in comparison with a large number of alkali, alkaline earth, transition and heavy metal ions. The sensor was used as indicator electrode in potentiometric titration of $\mathrm{Fe}(\mathrm{III})$ ions vs. EDTA.
\end{abstract}

KEY WORDS: Iron, Ion selective electrode, PVC membrane, Schiff base, Potentiometry

\section{INTRODUCTION}

Iron is widely distributed in nature and is one of the most important elements in biological systems. It plays a role in the transport and storage of oxygen and also in electron transport. Iron provides a fundamental structure of haemoglobin, myoglobine, haemenzymes and many cofactors involved in enzyme activities. It is well known that an iron deficiency is the most common cause of anemia. On the other hand, too much iron can cause several health problems. High levels of iron are associated with an increased risk of cancer, heart disease and other illnesses such as haemochromatosis [1-3]. Hence, the need to iron ion determination in clinical, medicinal, environmental and different industrial samples has created several methods to measure this analyte [4-7].

One of these methods which offer simplicity, rapidity and can be used as a reliable tool is ion-selective sensors. There are an increasing number of investigations about ion selective electrodes because of their ease in use and their selectivity characteristics. In analytical chemistry it is important to have methods with which trace determinations may be made directly, accurate and fast. However very few Fe(III)-selective sensors which offer simplicity, rapidity and reliability as an analytical tool have been reported [8-10].

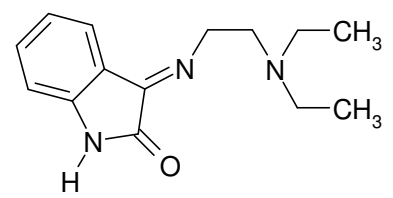

Figure 1. Structure of ionophore 3-(2-diethylamino-ethylimino)-1, 3-dihydro-indol-2-one (DEDIO).

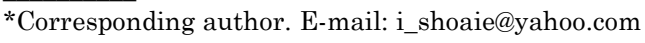


Recently, several highly selective and sensitive PVC-membrane ion selective electrodes (ISEs) for various metal ions have been reported [11-15]. In this study, we were also motivated to investigate the fabrication and characterization of a new ISE based on (DEDIO) (Figure 1) as a suitable ionophore.

\section{EXPERIMENTAL}

\section{Apparatus}

All potentiometric measurements were made at $25.0 \pm 0.1{ }^{\circ} \mathrm{C}$ with a $\mathrm{pH} / \mathrm{mV}$ meter (Zag Shimi, Iran) using proposed sensor in conjunction with a double junction $\mathrm{Ag} / \mathrm{AgCl}$ (Azar electrode, Iran) reference electrode. The prepared indoline-2,3-dione (isatin) was characterized by microanalysis using a Perkin Elmer (Waltham, MA) analyzer. ${ }^{1} \mathrm{H}$ and ${ }^{13} \mathrm{C}$ nuclear magnetic resonance (NMR) spectra were obtained using a Bruker Daltonics (Billerica, MA) AM 300 $\mathrm{MHz}$ spectrometer. Ultraviolet-visible spectra were recorded with a Beckman Coulter (Fullerton, CA) DU-7000 spectrometer and Fourier transforms infrared (FT-IR) spectra with a Shimadzu (Columbia, MD) DR-8001. Determination of ions was performed on a Varian Inc. (Palo Alto, CA) AA220 atomic absorption spectrometer under recommended conditions for each metal ion in the instrument manual.

\section{Reagents and materials}

Analytical reagent grade chemicals and doubly distilled water were used for preparing all the aqueous solutions. High molecular weight poly(vinyl chloride) powder (PVC), dioctylphthalate (DOP), dibutylphthalate (DBP), dimethylsebacate (DMS), and tetrahydrofuran (THF) were obtained from Aldrich (Steinheim, Germany). Sodium tetraphenyl borate (NaTPB) and 2nitrophenyl octyl ether (NPOE) were obtained from Fluka (Buchs, Switzerland). The nitrate and chloride salts of all cations used (all from Merck (Darmstadt, Germany) and Aldrich (Steinheim, Germany)) were of the highest available purity and used without any further purification, except for vacuum drying over $\mathrm{P}_{2} \mathrm{O}_{5}$. All metal salt solutions were freshly prepared by accurate dilution from their stock standard solution of $0.1 \mathrm{M}$, with distilled deionizer water. The concentration of solutions was checked by an atomic absorption spectrophotometer.

\section{Ionophore synthesis}

The procedure used for the preparation of 3-(2-diethylamino-ethylimino)-1,3-dihydro-indol-2one (DEDIO) was as follows: in the beginning isatin $(0.001 \mathrm{~mol}, 0.147 \mathrm{~g})$ was dissolved in ethanol $(35 \mathrm{~mL})$ using a magnetic stirrer; afterwards, N,N-Diethylethylenediamine $(0.001 \mathrm{~mol}$, $0.141 \mathrm{~mL}$ ) was added gradually to the solution then catalytic amount of acetic acid added and the reaction mixture refluxed for about $31 \mathrm{~h}$. After this time the reaction was completed as indicated by TLC and then the reaction mixture refrigerated overnight. The reaction mixture, which was filtered, washed with cold ethanol and recrystallized in a mixture of ethanol and ether, provided the desired product. The pure product was obtained in the form of brown powder, which was then characterized as follows: m.p.: $109-110^{\circ} \mathrm{C}$, yield: $54 \%$. IR $(\mathrm{KBr})\left(v_{\max }\right.$ $\left.\left(\mathrm{cm}^{-1}\right)\right)$ : 3425 and 3329, 1632, $1650(\mathrm{C}=\mathrm{O}), 1618(\mathrm{C}=\mathrm{N})$. Elemental $\mathrm{C}, \mathrm{H}, \mathrm{N}$ analysis, found: $\mathrm{C}$, 68.2; $\mathrm{H}, 7.89 ; \mathrm{N}, 17.14 \%$. Calculated for $\mathrm{C}_{14} \mathrm{H}_{17} \mathrm{~N}_{3} \mathrm{O}(245.33): \mathrm{C}, 68.54 ; \mathrm{H}, 7.81 ; \mathrm{N}, 17.13 \%$. ${ }^{1} \mathrm{H}$ NMR (300 MHz, DMSO solutions): $\delta 10.58(1 \mathrm{H}, \mathrm{s}, \mathrm{NH}), 7.59(1 \mathrm{H}, \mathrm{t}, \mathrm{J}=7.8 \mathrm{~Hz}, 1 \mathrm{CH}), 7.48$ $(1 \mathrm{H}, \mathrm{d}, \mathrm{J}=7.8 \mathrm{~Hz}, 1 \mathrm{CH}), 7.09(1 \mathrm{H}, \mathrm{t}, \mathrm{J}=7.6 \mathrm{~Hz}, 1 \mathrm{CH}), 9.98(1 \mathrm{H}, \mathrm{d}, \mathrm{J}=7.6 \mathrm{~Hz}, \mathrm{CH}), 3.11-$ $2.84\left(8 \mathrm{H}, \mathrm{m}, 4 \mathrm{CH}_{2}\right), 1.15-1.09\left(6 \mathrm{H}, \mathrm{m}, 2 \mathrm{CH}_{3}\right) .{ }^{13} \mathrm{C} \mathrm{NMR}(300 \mathrm{MHz}$, DMSO solutions): $\delta 165.3$, $138.8,122.1,161.3,118.6,128.6,130.1,123.2,45.1,60.9,49.2$, and 20.9. 


\section{Electrode preparation}

The procedure to prepare the PVC membrane included mixing the powdered PVC, the plasticizer, the ionophore DEDIO and the additive NaTPB dissolved in $3 \mathrm{~mL}$ of THF as the compositions shown in Table 1. The resulting mixture was transferred into a glass dish of $2 \mathrm{~cm}$ diameter; the solvent was evaporated slowly at room temperature until an oil concentrated mixture was obtained. A Pyrex or Teflon tube (3-5 mm i.d. on top) was dipped into mixture for about $11 \mathrm{~s}$ so that transparent membrane of about $0.3 \mathrm{~mm}$ thickness was formed. The tube then pulled out of the mixture and kept at room temperature for about $1 \mathrm{~h}$. The tube was then filled with internal filling solution $\left(1 \times 10^{-3} \mathrm{M}\right) \mathrm{Fe}\left(\mathrm{NO}_{3}\right)_{3}$ the electrode was finally conditioned for 24 $\mathrm{h}$ by soaking in a $1 \times 10^{-2} \mathrm{M}$ solution of ferric nitrate. $\mathrm{Ag} / \mathrm{AgCl}$ electrode was used as an internal reference electrode. The ratio of various ingredients, concentration of equilibrating solution and time of conditioning was optimized to provide membrane, which result in reproducible, and potentials with relatively little noise.

Table 1. Optimization of membrane ingredients.

\begin{tabular}{|c|c|c|c|c|c|c|}
\hline \multirow{2}{*}{ No } & \multicolumn{3}{|c|}{ Composition (w/w) \% } & \multirow{2}{*}{ NaTPB } & \multirow{2}{*}{$\begin{array}{c}\text { Slope } \\
(\mathrm{mV} / \mathrm{dec})\end{array}$} & \multirow{2}{*}{ Dynamic range (M) } \\
\hline & PVC & Plasticizer & DEDIO & & & \\
\hline 1 & 29.4 & 70.6, DBP & - & - & $3( \pm 1)$ & - \\
\hline 2 & 31.2 & $62.7, \mathrm{DBP}$ & 6.1 & - & $19( \pm 1)$ & $2.0 \times 10^{-5}-4.5 \times 10^{-4}$ \\
\hline 3 & 29.8 & $66.4, \mathrm{DBP}$ & - & 3.8 & $6( \pm 1)$ & - \\
\hline 4 & 29.4 & $61.3, \mathrm{DBP}$ & 4.9 & 4.4 & $26( \pm 1)$ & $2.0 \times 10^{-6}-5.0 \times 10^{-2}$ \\
\hline 5 & 29.4 & $61.2, \mathrm{NPOE}$ & 4.9 & 4.5 & $15( \pm 1)$ & $2.5 \times 10^{-5}-1.0 \times 10^{-3}$ \\
\hline 6 & 29.4 & $61.1, \mathrm{DOP}$ & 5.0 & 4.5 & $21( \pm 1)$ & $3.0 \times 10^{-6}-5.0 \times 10^{-2}$ \\
\hline 7 & 30.2 & 62.8, DMS & 4.1 & 2.9 & $25( \pm 1)$ & $2.0 \times 10^{-6}-5.0 \times 10^{-3}$ \\
\hline 8 & 31.5 & 59.1, DMS & 5.0 & 4.4 & $19( \pm 1)$ & $3.0 \times 10^{-6}-1.0 \times 10^{-2}$ \\
\hline
\end{tabular}

\section{Emf measurements}

All the emf measurements were carried out with the following cell assembly:

Ag-AgCl I internal solution $\left(1 \times 10^{-3} \mathrm{Fe}\left(\mathrm{NO}_{3}\right)_{3} \mid \mathrm{PVC}\right.$ membrane I test solution | $\mathrm{Ag}$ - $\left.\mathrm{AgCl}\right)$

All measurements were carried out in a $50 \mathrm{~mL}$ double-walled glass cell, with constant magnetic stirring of the test solution. The performance of the electrodes was investigated by measuring in the emf of ferric nitrate solutions prepared with concentration range of $10^{-1}$ to $10^{-7} \mathrm{M}$ by serial dilution. Activities were calculated according to Debye-Huckel procedure [16].

\section{RESULTS AND DISCUSSION}

\section{Preliminary experiments}

The structure of compound examined as ferric ion selective ionophore is presented in Figure 1. The ionophore is three dentate ligand and form stable complex with some transition metals including Fe(III). The key ingredient of such plasticized PVC membrane is the incorporated carrier that defines the selectivity of the electrodes via selective complex formation with the cation of interest due to its sufficient insolubility in water and the presence of donating nitrogen and oxygen atoms in its structure. Ligand DEDIO was expected to act as a suitable ion carrier in the PVC membranes with respect to special transition and heavy metal ions of proper size and charge. Thus in preliminary experiments, it was used a neutral carrier to prepare PVC-based 
membrane electrodes for a variety of metal ions. The potential response of the most sensitive electrodes, prepared under the same experimental conditions (except for $24 \mathrm{~h}$ conditioning in a $0.01 \mathrm{M}$ of the corresponding cations) is shown in Figure 2. As it can be seen, among different tested cations, $\mathrm{Fe}$ (III) with the most sensitive response seems to be suitably determined with the PVC membrane based on DEDIO and the emf responses obtained for all other cation-selective electrodes are much lower than the predictor by the Nernst equation. This is probably due to both the selective behavior of the ionophore against Fe(III) in comparison to some other metal ions and the rapid exchange kinetics of the resulting DEDIO-Fe(III) complexes.

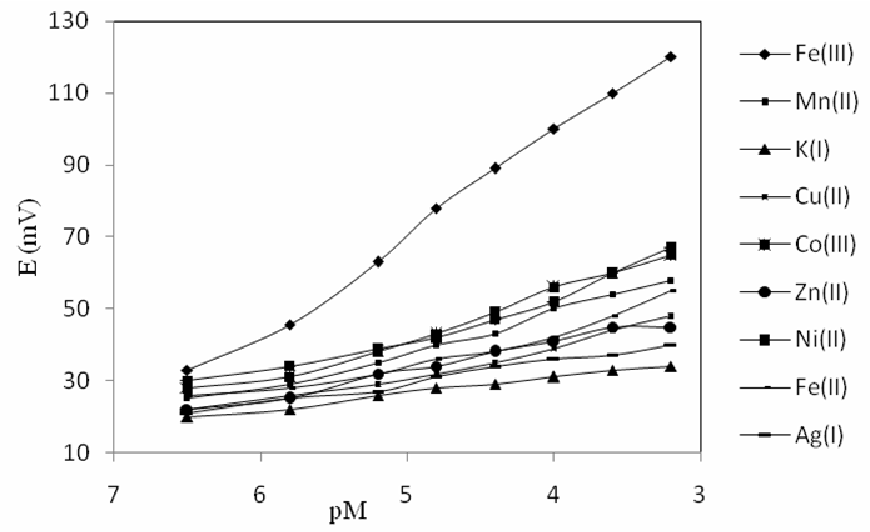

Figure 2. Potential response of various ion-selective electrodes based on ligand DEDIO conditions: membrane ingredients, 5.2\% ionophore, $29.4 \%$ PVC, $61.3 \%$ DBP and $4.4 \% \mathrm{NaTPB}$; internal solution, $1 \times 10^{-3} \mathrm{M}$ of each cation used. The electrodes have been conditioned in $1 \times 10^{-2} \mathrm{M}$ of the corresponding cation for $24 \mathrm{~h}$.

\section{Effect of membrane composition}

It is well known that the sensitivity and selectivity obtained for a given ion-selective electrode depends not only on the nature of ionophore used, but also significantly on the membrane composition and the properties of the plasticizer employed [16-20]. Thus the influences of the membrane composition and the nature of plasticizer on the response characteristics of Fe(III) ion-selective electrode based on DEDIO were investigated and the results summarized in Table 1. The nature and amount of plasticizer on the dielectric constant of the membrane phase, the mobility of the ionophore molecules and the state of ligand largely affect the response characteristics of ion-selective electrodes [21-24].

As can be seen in Table 1 among the four different plasticizers often used with PVCmembrane electrodes including NPOE, DOP, DMS and DBP, the best calibration parameter and mechanical characteristics of the membranes were observed in the case DBP, hence this plasticizer was used in further studies. This indicates the solvent medium of DBP is probably recognized in providing the best complexation environment between ferric ions and carrier. The results obtained indicate that the best performance was observed with the membrane electrode No. 4 , comprising the percent ratio as $29.4: 61.3: 4.4: 4.9$ for PVC : DBP : NaTPB : DEDIO constituents, respectively.

\section{Effect of $\mathrm{pH}$ on the potential response of the electrode}

Effect of $\mathrm{pH}$ on the response of the sensor was studied over two different concentrations $(1 \times$ $10^{-3} \mathrm{M}$ and $1 \times 10^{-4} \mathrm{M}$ ) of $\mathrm{Fe}(\mathrm{III})$ ions. Studies were carried out over a $\mathrm{pH}$ range of 1.5-9.5. 
Introducing $\mathrm{HNO}_{3}$ or $\mathrm{NaOH}$ drop wise adjusted the $\mathrm{pH}$ and the results are shown in Figure 3. The potential difference is independent of $\mathrm{pH}$ in the range 4.5-8.0. Therefore, this can be taken as the working $\mathrm{pH}$ range for the proposed electrode system. At $\mathrm{pH}$ value lower than 4 , a decrease in potential is observed, probably the electrode start responding to $\mathrm{H}^{+}$ions. At higher $\mathrm{pH}$ values, the deviation can be assigned to the formation of some hydroxyl complexes of $\mathrm{Fe}$ (III) ions in solution precipitates. The potentials are fairly constant in the $\mathrm{pH}$ range 4.5-8.0.

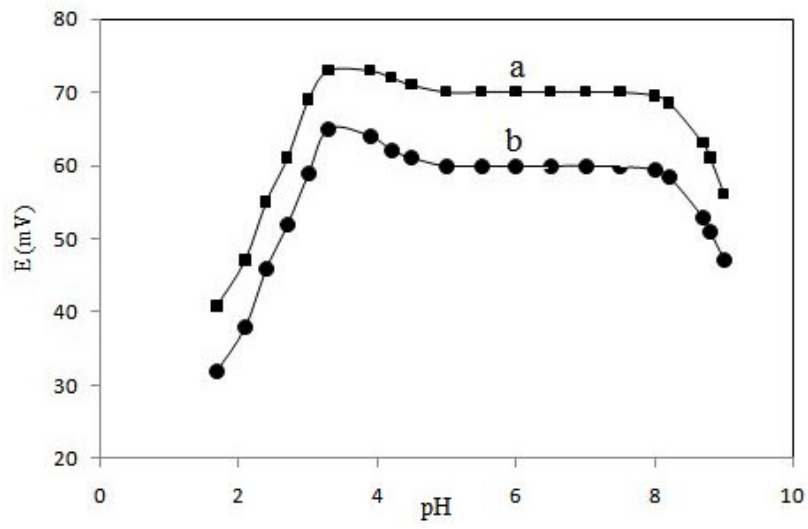

Figure 3. Effect of $\mathrm{pH}$ of test solutions on the response of Fe(III) selective electrode based on DEDIO (a) $1 \times 10^{-3} \mathrm{M}$ Fe(III); (b) $1 \times 10^{-4} \mathrm{M}$ Fe(III).

\section{Calibration curve and statistical data}

The proposed membrane electrode was examined with different concentrations of the inner reference solution from $1.0 \times 10^{-2}$ to $1.0 \times 10^{-5} \mathrm{M}$. Functioning of the membrane sensor with reference solutions of various $\mathrm{Fe}\left(\mathrm{NO}_{3}\right)_{3}$ concentration was found only a slight effect on the potential response of the electrode. A $1.0 \times 10^{-2} \mathrm{M}$ concentration of the reference solution is quite appropriate for smooth functioning of the membrane electrode system. The optimum equilibration time for the membrane electrode in the presence of $1.0 \times 10^{-2} \mathrm{M} \mathrm{Fe}\left(\mathrm{NO}_{3}\right)_{3}$, was 24 $\mathrm{h}$, after which it would generate stable potentials in contact with the iron solution. The electrode shows a linear response to the concentration of Fe(III) ion in the range of $2.0 \times 10^{-6}-5.0 \times 10^{-2}$ $\mathrm{M}$ in $\mathrm{pH} 5.5$ and $25^{\circ} \mathrm{C}$ (Figure 4). The slope of calibration graph was $26 \pm 1 \mathrm{mV}$ per decade. Here it should be mentioned that the critical response characteristics of the $\mathrm{Fe}^{3+}$ ion-selective electrode were assessed according to the IUPAC recommendation [25]. The limit of detection was $5.5 \times 10^{-7} \mathrm{M}$, driving from the intersection of the two extrapolated segments of the response potential-pFe ${ }^{3+}$ plot (Figure 4 ).

\section{Performance of the proposed electrode}

We measured the average time required for Fe(III) ion-selective electrode to reach a potential within $\pm 1 \mathrm{mV}$ of the final equilibrium value after successive immersion in a series of iron ion solution, each having a 10 -fold difference in concentration. The static response time of the membrane electrode thus obtained was $\sim 12 \mathrm{~s}$ and potentials stayed constant for $\sim 8 \mathrm{~min}$, after which only a very slow divergence within the months without any measurable change in response time, slope, or detection limit. The performance characteristics of the membrane remained unchanged when the potentials recorded either from low to high concentrations or vice versa. This means that the response was rapid and reversible. The membrane electrode 
prepared could be used for ten weeks without observing any change in response characteristics (week-to-week tested). The standard deviation of ten replicate measurements with one membrane within 6 weeks was $5.0 \%$. The membranes were stored in $0.01 \mathrm{M} \mathrm{Fe}$ (III) solution or dry when not in use. If the membrane was stored dry, it must be conditioned in a $0.01 \mathrm{M}$ iron nitrate solution for $24 \mathrm{~h}$. To evaluate the reproducibility of this electrode, a series of membranes (five) with similar composition No. 4 prepared and the response of these electrodes to Fe(III) ion concentrations were tested. The results show that the average of slopes, and linear dynamic ranges were $26 \pm 1 \mathrm{mV} /$ decade and $\left(2.0( \pm 0.3) \times 10^{-6}\right.$ to $\left.5.0( \pm 0.2) \times 10^{-2} \mathrm{M}\right)$, respectively. The standard deviation of measurements of $1.0 \times 10^{-5} \mathrm{M}$ to $\mathrm{Fe}(\mathrm{III})$ solution with these five electrodes was $\pm 1.5 \mathrm{mV}$.

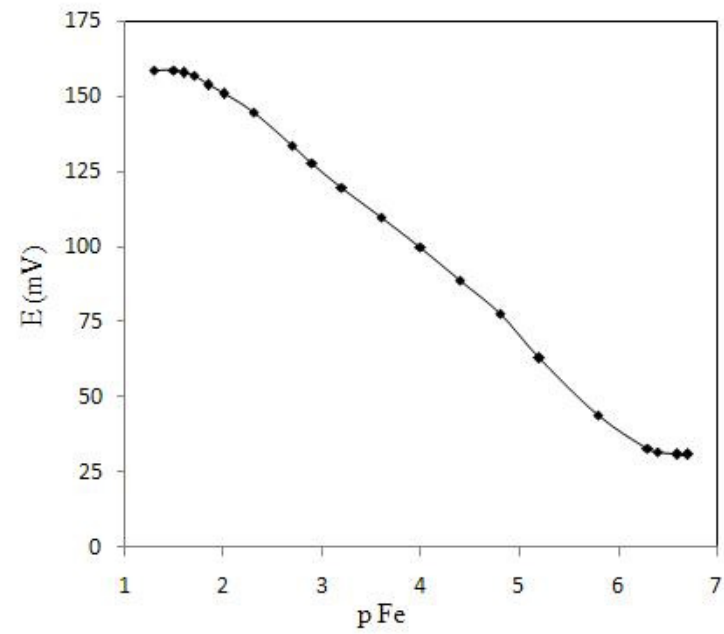

Figure 4. Calibration curve for Fe(III)-selective electrode based on DEDIO at $\mathrm{pH} \sim 5.5$.

\section{Potentiometric selectivity}

The selectivity behavior is obviously one of the most important characteristics of an ion selective electrode, determining whether a reliable measurement in the target sample is possible. To investigate the selectivity of the membrane electrode proposed, the potentials response were investigated in the presence of various interfering foreign ions. Figure 2 clearly shows the selective behavior of the PVC membrane electrode based on DEDIO for Fe(III) ion over other cationic species. The selectivity coefficients of the proposed membrane selective electrode were determined against a number of different cations by using separate solution method (SSM) [24].

According to the SSM, the potentiometric selectivity coefficients were determined using $1 \times$ $10^{-4} \mathrm{M}$ test solution of different ions at $\mathrm{pH} \sim 5.5$ and utilizing the equation:

$$
\log K_{F e(I I I), M}^{p o t}=\left(E_{j}-E_{i}\right) / S-\log a_{j}^{Z_{i} Z_{j}}+\log a_{i}
$$

where $E_{i}$ and $E_{j}$ are the measured emf for the solutions of interfering and $F e($ III) ions, respectively $Z_{i}$ and $Z_{j}$ are the charge of $F e(I I I)$ and interfering ion. $S$ the calibration slope of the sensor and $a_{i}$ and $a_{j}$ are the activity of $F e(I I I)$ and interfering ion, respectively. The resulting selectivity coefficients which are summarized in Table 2, indicate that the sensor is selective for $\mathrm{Fe}(\mathrm{III})$ ion in presence of interfering ions. 
Table 2. Selectivity coefficients of various interfering ions for Fe(III) ion-selective electrode based on DEDIO.

\begin{tabular}{|c|c|}
\hline Interfering ion & $-\log \mathrm{K}_{\mathrm{Fe}}{ }^{3+},{ }_{\mathrm{M}}{ }^{\mathrm{pot}}$ \\
\hline $\mathrm{Cu}^{2+}$ & 1.7 \\
\hline $\mathrm{Cr}^{2+}$ & 1.8 \\
\hline $\mathrm{Ni}^{2+}$ & 2.8 \\
\hline $\mathrm{Cd}^{3+}$ & 2.4 \\
\hline $\mathrm{Ca}^{2+}$ & 2.4 \\
\hline $\mathrm{Fe}^{2+}$ & 2.5 \\
\hline $\mathrm{Ag}^{+}$ & 2.6 \\
\hline $\mathrm{Na}^{+}$ & 1.8 \\
\hline
\end{tabular}

\section{Analytical applications}

The Fe(III) membrane sensor was found to work well under laboratory conditions. It was successfully used as an indicator electrode in the titration of $50 \mathrm{~mL}$ of $1.0 \times 10^{-3} \mathrm{M} \mathrm{Fe}$ (III) ions with a $1.0 \times 10^{-2} \mathrm{M}$ EDTA solution and the results are shown in Figure 5. As it is seen, the amount of ferric ions in solution can be accurately determined with the electrode.

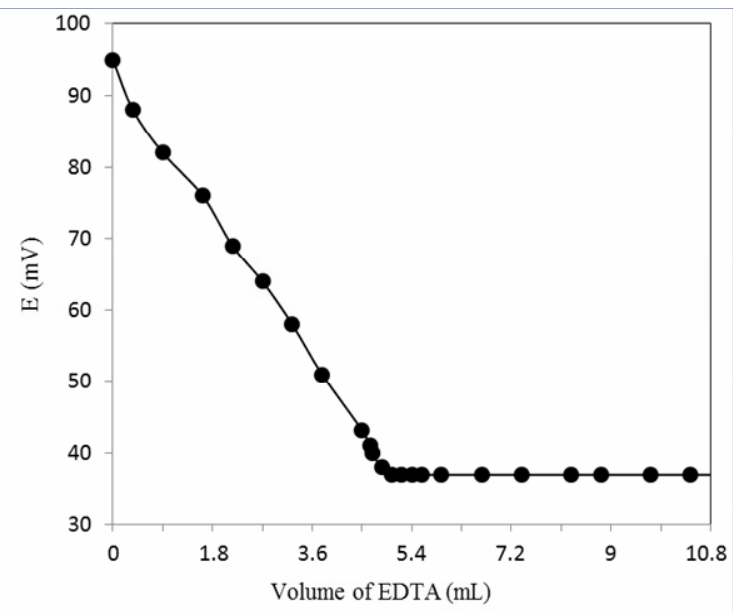

Figure 5. Potentiometric titration curve of $50 \mathrm{~mL}$ of $1.0 \times 10^{-3} \mathrm{M} \mathrm{FeCl}_{3}$ solution with $1.0 \times 10^{-2}$ M EDTA using the proposed membrane sensor as an indicator electrode.

Table 3. Comparison of the proposed ion selective sensor with the existing sensors.

\begin{tabular}{|c|c|c|c|c|c|}
\hline Ref. & $\begin{array}{c}\text { Working concentration } \\
\text { range }(\mathrm{M})\end{array}$ & $\begin{array}{c}\text { Slope } \\
\text { (mV/decade of } \\
\text { activity) }\end{array}$ & $\mathrm{pH}$ & $\begin{array}{c}\text { Response } \\
\text { time(s) }\end{array}$ & $\begin{array}{c}\text { Lifetime } \\
\text { (days) }\end{array}$ \\
\hline 8 & $3.5 \times 10^{-6}-4.0 \times 10^{-2}$ & $28.5 \pm 0.5$ & $4.5-6.5$ & $<15$ & 60 \\
\hline 26 & $1.0 \times 10^{-7}-1.0 \times 10^{-2}$ & $19.6 \pm 0.4$ & $1.6-4.3$ & 10 & 63 \\
\hline 27 & $1.0 \times 10^{-7}-1.0 \times 10^{-2}$ & $31.9 \pm 0.2$ & $3.2-7.1$ & 10 & 90 \\
\hline 28 & $1.0 \times 10^{-7}-1.0 \times 10^{-1}$ & $19.9 \pm 0.3$ & $3.0-6.3$ & $<12$ & 60 \\
\hline $\begin{array}{c}\text { Proposed } \\
\text { sensor }\end{array}$ & $2.0 \times 10^{-6}-5.0 \times 10^{-2}$ & 26.0 & $4.5-8.0$ & $<12$ & 70 \\
\hline
\end{tabular}

Bull. Chem. Soc. Ethiop. 2012, 26(1) 


\section{CONCLUSIONS}

The main advantages of the proposed potentiometric sensor are its simplicity of preparation, short conditioning time, fast response time, wide dynamic range, low detection limit, low cost, Nernstian behavior, and fairly good selectivity. The electrode has a life time of more than ten weeks. Consequently, the proposed sensor is comparable with the existing sensors in terms of response time, lifetime, slope, $\mathrm{pH}$ range, and concentration range (Table 3 ).

\section{REFERENCES}

1. Olivera, A.F.; Nobrega, J.A.; Fatibello-Filho, O. Talanta 1999, 49, 505.

2. Safavi, A.; Abdollahi, H.; Hormozi-Nezhad, M.R. Talanta 2002, 56, 699.

3. Costa, R.C.C.; Araújo, A.N. Anal. Chim. Acta 2001, 438, 227.

4. Wu, J.; Boyle, E.A. Anal. Chim. Acta 1998, 367, 183.

5. Obata, H.; Karatani, H.; Nakayama, E. Anal. Chem. 1993, 65, 1524.

6. Zolgharnein, J.; Abdollahi, H.; Jaefarifar, D.; Azimi, G.H. Talanta 2002, 57, 1067.

7. Shamspur, T.; Mashhadizadeh, M.H.; Sheikhshoaie, I. J. Anal. Atom. Spectrom. 2005, 20, 476.

8. Mashhadizadeh, M.H.; SheikhShoaei, I.; Monadi, N. Talanta 2004, 64, 1048.

9. Gupta, V.K.; Jain, A.K.; Agarwal, S.; Maheshwari, G. Talanta 2007, 71, 1964.

10. Mahmoud, W.H. Anal. Chim. Acta 2001, 436, 199.

11. Zamani, H.A.; Ganjali, M.R.; Adib, M. Sens. Actuators B 2007, 120, 545.

12. Abedi, M.R.; Zamani, H.A. Anal. Lett. 2008, 412251.

13. Zamani, H.A.; Ganjali, M.R.; Pooyamanesh, M.J. J. Braz. Chem. Soc. 2006, 17, 149.

14. Zamani, H.A. Anal. Lett. 2008, 41, 1850.

15. Zamani, H.A.; Ganjali, M.R.; Norouzi, P.; Meghdadi, S. Anal. Lett. 2008, 41, 902.

16. Kamata, S.; Bhale, A.; Fukunaga, Y.; Murata, A. Anal. Chem. 1988, 60, 2464.

17. Mashahdizadeh, M.H.; Momeni, A.; Razavi, R. Anal.Chim. Acta. 2002, 462, 245.

18. Mashahdizadeh, M.H.; Sheikhshoei, I. Talanta 2003, 60, 73.

19. Mashahdizadeh, M.H.; Sheikhshoaei, I. Anal. Bional. Chem. 2003, 375, 708.

20. Zamani, H.A.; Ganjali, M.R.; Seifi, N. Collect. Czechoslov. Chem. Commun. 2007, 72, 1189.

21. Bakker, E.; Buhlmann, P.; Pretsch, E. Chem. Rev. 1997, 97, 3083.

22. Yang, X.;Kumar, N.; Chi, H.; Hibbert, D.B.; Alexander, N.W. Electroanal. 1997, 9, 549.

23. Verpoorte, E.M.J.; Chan, A.D.C.; Harrison, D. Electroanal. 1993, 5, 845.

24. Umezawa, Y.; Buhlmann, P.; Umezawa, K.; Tohda, K.; amemiya, S. Pure. Appl. Chem. 2000, 72, 1851.

25. IUPAC Analytical Chemistry Division, Commission on Analytical Nomenclature, "Report: recommendations for nomenclature of ion-selective electrodes" Pure Appl. Chem. 1976, 48, 127.

26. Zamani, H.A.; Ganjali, M.R.; Behmadi, H.; Behnajady, M. A. Mater. Sci. Eng. C 2009, 29, 1535.

27. Wagiha, H.M. Anal. Chim. Acta 2001, 436, 199.

28. Babakhanian, A.; Gholivand, M.B.; Mohammadi, M.; Khodadadian, M.; Shockravi, A.; Abbaszadeh, M.; Ghanbary, A. J. Hazard. Mater. 2010, 177, 159. 